原著

\title{
赤血球抗体保有患者への抗原陽性血液の輸血症例調査
}

\author{
松田 仁志 \\ 全国国立大学附属病院輸血部会議技師研究会 \\ 東北大学医学部附属病院輸血部
}

(平成13年 4 月 3 日受付)

(平成14年 1 月 23 日受理)

\section{SURVEY OF ANTIGEN POSITIVE RED CELL TRANSFUSION TO IRREGULAR ANTIBODY CARRIER PATIENT}

\author{
Hitoshi Matsuda \\ The Medical Technologist Study Group to The Blood Transfusion Service \\ Conference of National University Hospitals \\ Blood Transfusion Service of Tohoku University Hospital
}

This report describes the results of a survey on the present state of incompatible blood transfusions other than $\mathrm{ABO}$ group red blood cell transfusion at national university hospitals. The survey population consisted of medical technologists of blood transfusion services at 43 national university hospitals in Japan. The questionnaire focused on incompatible blood transfusion in patients with irregular antibodies from 1991 through 1999.

A total of 110 cases were reported from 20 hospitals. Red cell transfusion was performed in 49 cases, and antibodies were divided into 7 categories $(\quad): 1$ ) Saline reactive antibody (8),2) Saline Enzyme reactive antibody (6), 3) Saline Enzyme Antiglobulin reactive antibody (7), 4) Saline Antiglobulin reactive antibody (4),5) Enzyme reactive antibody (10),6) Enzyme Antiglobulin reactive antibody (11),7) Antiglobulin reactive antibody (3). Of these cases, 24 were compatible transfusions for cold antibody and 25 inappropriate transfusions for $37^{\circ} \mathrm{C}$ antiglobulin reactive antibody. Nine patients of 25 incompatible transfusions showed abnormalities of subsequent clinical testing. The causes of incompatible transfusion were error in detection due to weakly reactive antibodies and omission of antiglobulin test and antibody history by physicians not used to testing. The present findings suggest the need for 24 hour support systems for transfusion services, and the necessity of considering whether compatible or identical transfusion is suitable for irregular antibodies showing positive on antiglobulin tests and the enzyme method, similar to the situation with the saline method. Anti-IgG antiglobulin test and DTT (Dithiothreitol) method are useful techniques in distinguishing clinically significant antibody from those difficult to determine.

I appreciate the extensive collaboration of Kazuhiko Itoh MD, Makoto Tamura MD, Masayoshi Minegishi MD and medical technologists at the Blood Transfusion Service of national university hospitals.

Key words : Irregular antibody, Incompatible transfusion, Compatible transfusion, Identical transfusion 


\section{はじめに}

近年，輸血事故防止対策を目的に日本輸血学会 は, 赤血球の $\mathrm{ABO}$ 型不適合輸血の実態調査を行 ない, その結果を報告した"1)。それでは輸血前検査 のもう一つの目的である $\mathrm{ABO}$ 型以外の不規則抗 体に対する輸血の実情はどうか. 本邦では,「輸血 療法の実施に関する指針」2)に基づき, 患者が ABO 型以外の抗体を保有する場合, $37^{\circ} \mathrm{C}$ 反応性抗体に 対しては対応する抗原が陰性の血液を検索して同 型血輸血を行ない，低温反応性の抗体の場合は, 臨床的意義がないとして対応する抗原の有無にか かわらず無作為に選んだ血液を輸血する適合血輸 血を行なう，ことになっている.

全国国立大学附属病院輸血部会議技師研究会 は，国立大学病院の輸血の現場で不規則抗体を保 有する患者にどのような適合血輸血と不適合血輸 血が行なわれているか及び，その抗体の反応性が 明らかで臨床検査による輸血予後が確認できた症 例を調査したので報告する。

\section{調查方法}

1）対象症例：輸血前後の不規則抗体検査及び 交差適合試験で陽性を示し, ABO 型以外の抗体 （以下，抗体）を保有する患者に抗原陽性の赤血球 が輸血された症例とした。

2) 調查施設：国立大学医学部附属病院 43 施設 とし, 輸血部検查技師に調査を依頼した。

3）調査期間：平成 3（1991）年から以前に逆上 ることも可として平成 11（1999）年までとした。

4）調查項目：抗体の反応性, 輸血前後の抗体 価, 抗原陽性赤血球の輸血本数, 輸血後の臨床検 查成績とした。患者の疾患名, 輸血歴, 妊娠歴, 手術歴, 輸血契機, 輸血後の患者症状については 調査を行なっていない.

\section{結 果}

Table 1 にまとめた.

1）報告された輸血症例：43 施設のうち 20 施 設から 110 症例の報告を受けた。その中で明らか に抗体に対応する抗原陽性の赤血球が輸血された ものは 49 症例であった. 他は, 赤血球以外の血液 製剤や抗体の反応性が不明のものであった.

2）抗体検查法：抗体は, 室温生食法・酵素法・
抗グロブリン試験の何れかの検查方法で検出され たものである．酵素法は，ブロメリンかフィシン の何れかを用いていたが，一段法・二段法の区分 はしていない，抗グロブリン試験には，添加され る反応増強・時間短縮牏としてアルブミン （BSA/PBA）あるいは低イオン強度溶液（LISS/ LISP/OAES) が用いられており，それぞれの反応 温度・反応時間は施設により異なっていた。 反応 の判定は, 未検査 (NT), 室温即時遠心判定 (RT • IS), $37^{\circ} \mathrm{C} 15$ 分間反応 $(37,15)$ とし, 陰性 $(-)$, 陽性（+）に区分した，反応の判定時期は，輸血 前・後か, 交差適合試験時か, 抗体スクリーニン グ検查時か，そのいずれかを特定していない．抗 体価は，測定した反応条件のうち力価の最も高い 值を記載した。

3）抗原陽性血液の輸血本数：赤血球製剂は, WB (全血)，CRC (濃厚赤血球)，LPRC (白血球 除去赤血球) 3 種類であり, 輸血本数は, 1 から 32 単位に及んだ. $200 \mathrm{~m} l \cdot 400 \mathrm{~m} l$ 由来製剤を 2 -, 4-で区分し，その後に単位数值を示した. 輸血さ れた赤血球が抗体に対応する抗原陽性血液である ことは, 事後的に血液型検査を行ない確認した。

4）輸血後の臨床検査：輸血後の臨床検査結果 を,(0) 特記すべき検查值の変動がない,（1）へモ グロビン尿の観察，(2) $\mathrm{LDH} \cdot \mathrm{K}$ 值の上昇，(3) 総 ビリルビン $1 \mathrm{mg} / \mathrm{d} l$ 以上の上昇, (4) 直接抗グロブ リン試験の陽性化，の数字で表記した。

5）抗体の反応性, 輸血後の抗体価, 臨床検査值 の変動：49症例の抗体は, 室温生食法, 酵素法, 抗グロブリン試験の反応の組み合わせから以下の 7 種類に分類された.

（1）室温生食法反応性抗体（No. 1-No. 8）：室温 生食法のみが陽性で酵素法, 抗グロブリン試験が 陰性の抗体である. 血液型特異性は, 抗 $\mathrm{P}_{1}$, 抗 $\mathrm{Le}^{\mathrm{a}}$ $+\mathrm{Le}^{\mathrm{b}}$ ，抗 Le $\mathrm{e}^{\mathrm{b}}$ であった. No. 7 の抗 $\mathrm{Le}^{\mathrm{b}}$ で $\times 4$ から $\times 16$ に抗体価の上昇が認められた。臨床検査での 変動を示すものはなかった。

（2）室温生食法・酵素法反応性抗体（No. 9-No. 14）：室温生食法と酵素法が陽性で抗グロブリン 試験が陰性の抗体である。血液型特異性は, 抗 I, 抗 $\mathrm{P}_{1}$, 抗 $\mathrm{Le}^{\mathrm{a}}$ ，抗 $\mathrm{Le}^{\mathrm{b}}$ であった. No. 14 の抗 $\mathrm{Le}^{\mathrm{b}}$ 
Table 1 Irregular antibodies classification and reactivity of patients receiving antigen positive red cells

\begin{tabular}{|c|c|c|c|c|c|c|c|c|}
\hline \multirow{2}{*}{ No } & \multirow{2}{*}{$\begin{array}{l}\text { Antibody } \\
\text { specificity }\end{array}$} & \multicolumn{3}{|c|}{ Test method } & \multicolumn{2}{|c|}{ Titer } & \multirow{2}{*}{$\begin{array}{l}\text { Antigen }(+) \\
\text { red cell trans }\end{array}$} & \multirow{2}{*}{$\begin{array}{c}\text { Laboratory } \\
\text { evidence }\end{array}$} \\
\hline & & Saline & Enzyme & Antiglobulin & pre trans & post trans & & \\
\hline \multicolumn{9}{|c|}{ Saline reactive antibody } \\
\hline 1 & $P_{1}$ & $+(19,15)$ & $-(B r o, 37,15)$ & $-(\mathrm{PBA})$ & NT & NT & 2WRC-2 & 0 \\
\hline 2 & $P_{1}$ & $+(\mathrm{RT}, 5)$ & $-($ Bro, 37,15$)$ & $-(37,60)$ & NT & NT & 2CRC-4 & 0 \\
\hline 3 & $\mathrm{P}_{1}$ & $+(\mathrm{RT}, 5)$ & $-(B r o, 37,15)$ & $-(\mathrm{ALB})$ & 1 & 1 & 2CRC-1 & 0 \\
\hline 4 & $\mathrm{Le}^{\mathrm{a}}, \mathrm{Le}^{\mathrm{b}}$ & $+(\mathrm{RT}, 5)$ & $-($ Bro, 37,15$)$ & $-(37,60)$ & 2 & $<1$ & 2CRC-3 & 0 \\
\hline 5 & $\mathrm{Le}^{\mathrm{b}}$ & $+(\mathrm{RT}, 5)$ & $-($ Bro, 37,15$)$ & $-(37,60)$ & NT & NT & 2CRC-1 & 0 \\
\hline 6 & $\operatorname{Le}^{b}$ & $+(\mathrm{RT}, 5)$ & $-($ Bro, 37,15$)$ & $-(37,60)$ & 1 & $<1$ & 2CRC-1 & 0 \\
\hline 7 & $\operatorname{Le}^{b}$ & $+(\mathrm{RT}, 5)$ & $-($ Bro, 37,60$)$ & $-(37,60)$ & 4 & 16 & 2CRC-14 & 0 \\
\hline 8 & $L^{b}{ }^{b}$ & $+(\mathrm{RT}, \mathrm{IS})$ & $-(\mathrm{Bro}, 37,15)$ & $-(\mathrm{PBA})$ & NT & NT & 2WB-20 & 0 \\
\hline \multicolumn{9}{|c|}{ Saline Enzyme reactive antibody } \\
\hline 9 & I & $+(\mathrm{RT}, \mathrm{IS})$ & $+($ Bro, 37,15$)$ & $-($ LISS $)$ & NT & NT & 2CRC-2 & 0 \\
\hline 10 & $P_{1} ?$ & $+(\mathrm{RT}, \mathrm{IS})$ & $+(\mathrm{Bro}, 37,15)$ & $-(37,60)$ & NT & NT & 2CRC-9 & 2 \\
\hline 11 & $P_{1}$ & $+(\mathrm{RT}, 5)$ & $+(B r o, 37,15)$ & $-(\mathrm{ALB})$ & 1 & 1 & 2LPRC-5 & 0 \\
\hline 12 & $\mathrm{Le}^{\mathrm{a}}$ & $+(\mathrm{RT}, \mathrm{IS})$ & $+($ Fici, 37, 30) & $-($ LISP) & NT & NT & 2CRC-1 & 0 \\
\hline 13 & Le $^{b}$ & $+(\mathrm{RT}, 15)$ & $+($ Fici, 37, 10) & $-(37,15)$ & 8 & 4 & 4CRC-1 & 0 \\
\hline 14 & $\operatorname{Le}^{b}$ & $+(\mathrm{RT}, 5)$ & $+($ Bro, 37,15$)$ & $-(\mathrm{ALB})$ & 2 & 4 & $2 \mathrm{RC}-4$ & 0 \\
\hline \multicolumn{9}{|c|}{ Saline Enzyme Antiglobulin reactive antibody } \\
\hline 15 & $\mathrm{Le}^{\mathrm{a}}, \mathrm{P}_{1}$ & $+(20,15)$ & $+($ Fici, 37, 10) & $+(37,15)$ & $<1$ & 1 & 2WB-1 & 0 \\
\hline 16 & $\mathrm{Le}^{\mathrm{a}}$ & $+(\mathrm{RT}, \mathrm{IS})$ & $+($ Fici, RT, 10) & $+(\mathrm{OAES})$ & 4 & 1 & 2CRC-5 & 0 \\
\hline 17 & $\mathrm{Le}^{\mathrm{a}}$ & $+(\mathrm{RT}, \mathrm{IS})$ & $+($ Fici, 37, 30) & $+(37,60)$ & NT & NT & 4CRC-2 & 0 \\
\hline 18 & $\mathrm{Le}^{\mathrm{a}}$ & $+(\mathrm{RT}, \mathrm{IS})$ & $+($ Fici, 37, 30) & $+(37,60)$ & NT & NT & 4CRC-3 & 0 \\
\hline 19 & $\mathrm{Le}^{\mathrm{a}}$ & $+(\mathrm{RT}, \mathrm{IS})$ & $+($ Fici, 37, 30) & + (LISP) & NT & NT & 4CRC-2 & 0 \\
\hline 20 & $\mathrm{Le}^{\mathrm{b}}$ & $+(\mathrm{RT}, 10)$ & $+($ Fici, RT, 10) & $+(\mathrm{OAES})$ & 1 & 1 & 4CRC-3 & 0 \\
\hline 21 & $\mathrm{Le}^{\mathrm{b}}$ & $+(\mathrm{RT}, 10)$ & $+($ Fici, RT, 10) & $+(\mathrm{OAES})$ & 4 & 4 & 4CRC-4 & 3 \\
\hline \multicolumn{9}{|c|}{ Saline Antiglobulin reactive antibody } \\
\hline 22 & M & $+(\mathrm{RT}, \mathrm{IS})$ & $-($ Bro, 37,15$)$ & $+(\mathrm{PBA})$ & $<1$ & NT & 2WB-8 & $2 \cdot 3$ \\
\hline 23 & M & $+(\mathrm{RT}, 10)$ & - (Fici, RT, 10) & $+(\mathrm{OAES})$ & 1 & $<1$ & 4CRC-3 & $3 \cdot 4$ \\
\hline 24 & M & $+(\mathrm{RT}, 10)$ & - (Fici, RT, 10) & $+(\mathrm{OAES})$ & NT & NT & 2WB-11 & 0 \\
\hline 25 & M & $+(\mathrm{RT}, \mathrm{IS})$ & - (Fici, 37, 30) & $+($ LISP $)$ & 32 & NT & 2CRC-3 & 0 \\
\hline \multicolumn{9}{|c|}{ Enzyme reactive antibody } \\
\hline 26 & $\mathrm{P}_{1}$ & $-(20,15)$ & $+($ Fici, 37, 10) & $-(37,15)$ & 4 & 2 & 4CRC-1 & 0 \\
\hline 27 & $\mathrm{P}_{1}$ & - (RT, IS) & $+(\mathrm{Bro}, 37,15)$ & - (LISS) & NT & NT & 2WB-2 & 0 \\
\hline 28 & $\mathrm{Le}^{\mathrm{a}}$ & $-(\mathrm{RT}, \mathrm{IS})$ & $+($ Fici, 37, 30) & - (LISP) & NT & NT & 4CRC-5 & 0 \\
\hline 29 & $\mathrm{Le}^{\mathrm{a}}$ & $-(\mathrm{RT}, \mathrm{IS})$ & $+($ Fici, 37,30$)$ & $-($ LISP) & NT & NT & 2CRC-3 & 0 \\
\hline 30 & $\mathrm{Le}^{\mathrm{a}}$ & - (RT, IS) & $+($ Fici, 37, 30) & - (LISP) & NT & NT & 2CRC-3 & 0 \\
\hline 31 & $\mathrm{Le}^{\mathrm{a}}$ & - (RT, IS) & $+($ Fici, 37, 30) & - (LISP) & NT & NT & 4CRC-10 & 0 \\
\hline 32 & $\mathrm{Le}^{\mathrm{a}}$ & - (RT, IS) & $+($ Fici, 37, 30) & - (LISP) & NT & NT & 2CRC-1 & 0 \\
\hline 33 & $\mathrm{Le}^{\mathrm{a}}$ & - (RT, IS) & $+($ Fici, 37, 30) & - (LISP) & 2 & NT & 2CRC-5 & 0 \\
\hline 34 & $\mathrm{Le}^{\mathrm{a}}$ & - (RT, IS) & $+($ Fici, 37, 30) & - (LISP) & NT & NT & 4CRC-1 & 0 \\
\hline 35 & $\mathrm{Le}^{\mathrm{b}}$ & $-(\mathrm{RT}, 15)$ & $+($ Fici, 37, 10) & $-(37,15)$ & 2 & 2 & 2CRC-2 & 0 \\
\hline \multicolumn{9}{|c|}{ Enzyme Antiglobulin reactive antibody } \\
\hline 36 & $\mathrm{E}, \mathrm{c}$ & $-(22,60)$ & $+($ Fici, 37, 60) & $+(\mathrm{ALB})$ & $\mathrm{E} 4, \mathrm{c} 2$ & NT & 2CRC-3 & 0 \\
\hline 37 & $\mathrm{E}$ & $-(22,60)$ & $+($ Fici, 37,60$)$ & $+(\mathrm{ALB})$ & 1 & 1 & 2CRC-2 & 0 \\
\hline 38 & $\mathrm{E}$ & $-(22,60)$ & $+($ Fici, 37, 60) & $+(\mathrm{ALB})$ & 2 & 8 & 2CRC-5 & 0 \\
\hline 39 & $\mathrm{E}$ & - (RT, IS) & $+($ Fici, 37, 15) & $+(37,60)$ & 8 & 16 & 4CRC-1 & $2 \cdot 3 \cdot 4$ \\
\hline 40 & $\mathrm{E}$ & - (RT, IS) & $+($ Bro, 37,15$)$ & $+(\mathrm{PBA})$ & $<1$ & 4 & 2CRC-4 & 1 \\
\hline 41 & $\mathrm{Le}^{\mathrm{a}}, \mathrm{E}$ & - (RT, IS) & $+($ Fici, 37, 30) & $+(\mathrm{LISP})$ & 8 & NT & 4CRC-2 & 0 \\
\hline 42 & $\mathrm{Le}^{\mathrm{a}}$ & - (RT, IS) & $+($ Fici, 37, 30) & $+(37,60)$ & NT & NT & 4CRC-1 & 0 \\
\hline 43 & $\mathrm{Le}^{\mathrm{a}}, \mathrm{Le}^{\mathrm{b}}$ & $-(20,15)$ & $+($ Fici, 37, 10) & $+(37,15)$ & 2 & 32 & 4WB-4 & 0 \\
\hline 44 & $\mathrm{Le}^{\mathrm{b}}$ & $-(\mathrm{RT}, 10)$ & $+($ Fici, RT, 10) & + (OAES) & 2 & 8 & 4CRC-2 & 3 \\
\hline 45 & $\mathrm{Le}^{\mathrm{b}}$ & $-(\mathrm{RT}, 10)$ & $+($ Fici, RT, 10) & $+(\mathrm{OAES})$ & 1 & 2 & 4CRC-4 & 0 \\
\hline 46 & $\operatorname{Le}^{b}$ & $-(\mathrm{RT}, 10)$ & $+($ Fici, RT, 10) & + (OAES) & 1 & $<1$ & 2CRC-2 & 0 \\
\hline \multicolumn{9}{|c|}{ Antiglobulin reactive antibody } \\
\hline 47 & $\mathrm{C} ?$ & - (RT, IS) & $-(\mathrm{Bro}, 37,15)$ & $+(\mathrm{POLB})$ & NT & NT & 2CRC-32 & 3 \\
\hline 48 & $\mathrm{C}$ & - (RT, IS) & - (Bro, 37, 15) & $+(\mathrm{POLB})$ & NT & 2 & 2WB-5 & 1 \\
\hline 49 & $\mathrm{~S}$ & $-(\mathrm{RT}, \mathrm{IS})$ & $-(\mathrm{Bro}, 37,15)$ & $+(\mathrm{PBA})$ & NT & NT & 2CRC-5 & $1 \cdot 3$ \\
\hline
\end{tabular}

Test method: $37,15=37^{\circ} \mathrm{C}, 15 \mathrm{~min}, \quad \mathrm{RT}, 5=$ Room temperature $5 \mathrm{~min}, \quad$ IS $=$ Immediate spin, Bro $=$ Bromeline, Fici $=$ Ficin, LISS =Low ionic strength solution, $\mathrm{Alb}=$ Albumin, $\mathrm{BSA}=$ Bovine serum albumin, $\mathrm{PBA}=$ Polymerized bovine albumin, $\mathrm{POLB}=$ Polybrene, LISP =Liss polybrene, OAES $=$ Ortho enhancement solution, Titer: pre trans $=$ pre transfusion, post trans $=$ post transfusion, NT = not tested, Antigen $(+)$ : red cell trans $=$ red cell transfusion units, WRC $=$ Washed red cells, CRC $=$ Concent rated red cells, $\mathrm{WB}=\mathrm{Whole}$ blood, $\mathrm{LPRC}=$ Leucocyte poor red cells, Laboratory evidence: $0=$ Clinical data no changed, $1=$ Hemoglobinuria, $2=$ high $\mathrm{LDH} \cdot \mathrm{K}, \quad 3=$ Bilirubin $1 \mathrm{mg} / \mathrm{d} l>, \quad 4=$ Direct antiglobulin test positive. 
で $\times 2$ から $\times 4$ へ抗体価の上昇が認められた. No. 10 の抗 $P_{1}$ （？）は，特異性を確定できなかった抗 体であるが, $\mathrm{LDH} \cdot \mathrm{K}$ 值の上昇を認めている.

（3）室温生食法・酵素法・抗グロブリン試験反 応性抗体 (No. 15-No. 21)：室温生食法, 酵素法, 抗グロブリン試験の全ての検査法で陽性を示した 抗体である. 血液型特異性は, 抗 $\mathrm{Le}^{\mathrm{a}}+\mathrm{P}_{1}$, 抗 $\mathrm{Le}^{\mathrm{a}}$ ，抗 Le $\mathrm{e}^{\mathrm{b}}$ であった。抗体価の上昇が認められた ものはなかった. No. 21 の抗 Le ${ }^{\mathrm{b}}$ は総ビリルビン の上昇が認められた.

（4）室温生食法・抗グロブリン試験反応性抗体 （No. 22-No. 25）：室温生食法と抗グロブリン試験 が陽性で酵素法が陰性の抗体である. 血液型特異 性は，いずれも抗 M であった. No. 22 は LDH・K 值, 総ビリルビンの上昇, No. 23 は総ビリルビンの 上昇, 直接抗グロブリン試験陽性が認められた。

（5）酵素法反応性抗体（No.26-No. 35）：酵素法 のみが陽性で室温生食法, 抗グロブリン試験が陰 性の抗体である. 血液型特異性は, 抗 $\mathrm{P}_{1}$, 抗 $\mathrm{Le}^{\mathrm{a}}$, 抗 Le $\mathrm{e}^{\mathrm{b}}$ で, 抗体価, 臨床検査で変動は見られなかっ た。

（6）酵素法・抗グロブリン試験反応性抗体 (No. 36-No.46）：酵素法と抗グロブリン試験が陽性で 室温生食法が陰性の抗体である. 血液型特異性は, 抗 $\mathrm{E}+\mathrm{c}$, 抗 $\mathrm{E}$ ，抗 $\mathrm{Le}^{\mathrm{a}}+\mathrm{E}$ ，抗 $\mathrm{Le}^{\mathrm{a}}$ ，抗 $\mathrm{Le}^{\mathrm{a}}+\mathrm{Le}^{\mathrm{b}}$, 抗 Le ${ }^{b}$ であった. No. 38 の抗 $\mathrm{E}$ は $\times 2$ から $\times 8$, No. 39 の抗 $\mathrm{E}$ は $\times 8$ から $\times 16$ 人, No. 43 の抗 $\mathrm{Le}^{\mathrm{a}}$ $+\mathrm{Le}^{\mathrm{b}}$ は $\times 2$ から $\times 32$ へ, No. 44 の抗 Le ${ }^{\mathrm{b}}$ は $\times 2$ か ら $\times 8$ へ抗体価の上昇が認められた. No. 39 の抗 $\mathrm{E}$ は $\mathrm{LDH} \cdot \mathrm{K}$ 值および総ビリルビンの上昇, 直接 抗グロブリン試験陽性を認め, No. 40 の抗 $\mathrm{E}$ はへ モグロビン尿が観察され, No. 44 の抗 Le $\mathrm{b}^{\mathrm{b}}$ は総ビ リルビンの上昇が認められた。

（7）抗グロブリン試験反応性抗体（No. 47-No. 49）：抗グロブリン試験のみが陽性で室温生食法 と酵素法が陰性の抗体である。血液型特異性は, 抗 C, 抗 Sであった. No. 47 の抗 C ( ? ) は, 特異 性を確定できなかった抗体であるが総ビリルビン の上昇を示し, No. 48 の抗 C は, ヘモグロビン尿 が観察され, No. 49 の抗 S は, 総ビリルビンの上 昇とへモグロビン尿が認められた。

\section{考察}

1）抗体保有時の輸血の是非：49症例は, 全て 輸血前検査で適合と判定されて輸血されたもので ある. しかし, 結果的に不適合輸血と判定される ものが含まれていた. No. 1 から No. 8 の室温生食 法反応性抗体は, 一部抗体価の上昇を見た抗体も あったが臨床検査の変動は確認されなかった。こ の抗体への輸血は, 低温反応性抗体と判断し, 抗 原の有無に関係なく無作為に輸血されたものであ るが適合血輸血と判定できるものである. No. 9 から No. 14 の室温生食法・酵素法反応性抗体は, No. 10 の抗 $P_{1}$ （？）を抗体同定と反応性の結果の 再確認を要するために保留すると, 臨床検査の変 動が確認されず適合血輸血とすることができる. 同様に No. 26 から No. 35 の酵素法反応性抗体も 適合血輸血と判定できる. しかし, No. 36 から No. 49 の酵素法を含む抗グロブリン試験反応性抗体 は，抗体価の上昇を示した抗体 $(6 / 14)$, 臨床検査 の変動を示した抗体 $(6 / 14)$ が最も多く見られた.

これらの抗体は, 輸血にとって $37^{\circ} \mathrm{C}$ 反応性の臨床 的に重要な抗体であり, 本来, 患者と同型血液を 検索して輸血すべきもので, 明らかな不適合血輸 血であった。一方, No. 15 から No. 25 までの室温 生食法・酵素法・抗グロブリン試験反応性抗体と 室温生食法・抗グロブリン試験反応性の抗体は, 抗グロブリン試験陽性であるが室温生食法反応性 抗体が酵素法や抗グロブリン試験へ凝集を持ち込 んだ可能性もあり臨床的に問題がない場合も考え られる3).この中には抗体価の上昇を示すものは なかったが, 臨床検査の変動を示した抗体 $(3 / 11)$ もあり, $37^{\circ} \mathrm{C}$ 反応性の抗体であるかの判定が難し い抗体である. 輸血判断の難しいこれらの抗体に 対する輸血は，これまでの経験から抗体の血液型 特異性で判断したり, 室温生食法の検査判定を行 なわず抗グロブリン試験の結果に基づいて行なわ れてきだ) . 抗体が抗グロブリン試験反応性か どうかを確認する方法は, 抗 IgG 抗グロブリン試 験 ${ }^{9} や$ DTT (Dithiothreitol) 処理 ${ }^{10}$ が実用的で有用 である.これを No. 15 から No. 25 までの抗体に実 施し, その結果を確認できれば抗体の反応性区分 が今回の結果と異なり, 適合血輸血と不適合血輸 
血に分けられる可能性がある．特に，臨床検査の 変動を示したNo. 21 から No. 23 が抗グロブリン 試験反応性抗体であることを証明できれば,「抗グ ロブリン試験で陽性を示す抗体は副作用を起こす ことがあり，室温生食法・酵素法で反応しても抗 グロブリン試験で反応しなければ副作用は起こら ない」との結論づけが可能となるであろう. 尚, 総ビリルビンの上昇が認められたNo. 21 , No. 44 の抗 Le ${ }^{\mathrm{b}}$ は検査結果と臨床経過の再確認が必要で ある。

室温生食法・酵素法・抗グロブリン試験反応性 の抗体に対する輸血の是非や抗体の処理法は，今 後，本邦のデー夕を集積して輸血療法の実施に関 する指針に明記されることが望まれる。

2）抗体保有患者への輸血調查：当初，本調査 は，低温反応性抗体の臨床的意義の否定のための 本邦における成績の集積を目的に行なわれた ${ }^{11}$. その結果，低温反応性抗体に対して半数以上の施 設が抗原検索を行なわず適合血として輸血してい ることが判明した．しかし，例数を重ねるにつれ， $37^{\circ} \mathrm{C}$ 反応性抗体に対する抗原陽性の輸血症例も 報告されるようになり，43 施設の約半数から調査 報告を受けていないが, $\mathrm{ABO}$ 型以外の不適合輸血 が予想に反し少なからず行なわれているのではな いかと推測された. 幸い, $\mathrm{ABO}$ 型以外の不適合輸 血による副作用が患者を致命的な状況に至らしめ ることがごく少ないことは救いである.しかし， 軽微な副作用といえども重症の患者にとっては臨 床上問題となることがあるので避けなければなら ない. 今後, $\mathrm{ABO}$ 型不適合輸血同様に国内の組織 的な実態調查を行ない原因を究明して輸血副作用 防止対策をはかることが望まれる.

3） $37^{\circ} \mathrm{C}$ 反応性抗体に対する不適合輸血の契 機：49症例全ての輸血契機は, 判明していない. 今後, この種の調査には輸血契機の項目を含むこ とが望まれる. 今回判明した抗グロブリン試験が 陽性を示す抗体への輸血契機は, 検查判定時の抗 体の見逃しと患者の過去の抗体情報の見逃しで あった. 見逃しの原因は，すでに報告 ${ }^{12)}$ があるが，

（1）時間外で検查手技に不慣れな担当医師の検査 が陽性反応を示す抗体を検出できなかった，
時間外や緊急時で簡易法による交差適合試験のた めに抗グロブリン試験反応性抗体を検出できな かった，（3）過去に臨床的に重要な抗体の保有歴 のある患者情報が確認されず時間が経過して抗体 が消失し輸血前検查で検出できなかった，ことが あげられた，見逃しの防止対策は，（1）検查技術 に習熟した検査技師の 24 時間配置体制を作る，

(2) 簡略化した検查では抗グロブリン試験の後追 い検査が必要である，（3）患者の抗体保有歴を直 ちに参照出来るシステムを整備する，などがあげ られよう。

\section{まとめ}

今回の調査後, 49 症例の患者で重症の輸血副作 用により危機に陥ったという報告は受けていな w.

$\mathrm{ABO}$ 型不適合輸血事故は,多くは輸血実施者の 事務的過誤により発生することが知られている が, $\mathrm{ABO}$ 型以外の不適合輸血は, 輸血部側の輸血 検査上の判定技術や検查法の選択, 情報伝達の不 備に起因することが明らかとなった.

輸血部は, 24 時間体制の整備が今後の課題であ る. 単に負担軽減のための自動化や検査技師の増 員をはかるのではなく，血液センターとの抗体保 有患者のための円滑な適合血液確保交涉術や臨床 の責任者に輸血実施の判断を惑わすことのない情 報提供術を教育・支援することが大事である．職 員は，輸血認定医を中心として臨床の担当医と連 携を保ちながら必要最小限の輸血にとどめ, 予後 を監視する体制を作り，患者に安全な輸血が行な われるよう努めなければならない。

謝辞：この調查にご協力をいただいた東北大学輸血部 の検査技師をはじめ, 全国国立大学輸血部会議技師研究会 の方々に厚く御礼を申し上げます．また，本稿作成にご理 解下さいました伊藤和彦先生（全国国立大学輸血部会議会 長, 京都大学医学部附属病院輸血部部長・教授), ご指導を いただきました田村眞先生（新潟県赤十字血液センター所 長, 前東北大学医学部附属病院輸血部副部長 - 助教授), 峯 岸正好先生（東北大学医学部附属病院輸血部副部長 - 助教 授）に深く感謝を申し上げます。 


\section{文献}

1）柴田洋一, 他： $\mathrm{ABO}$ 型不適合輸血実態調查の結 果報告. 日本輸血学会雑誌, 46 (6)：545-564, 2000.

2）血液製剂調査機構編：輸血療法の実施に関する 指針．血液製剂の使用にあたって，1999,33-46.

3) Mallory, D. : Controversies in transfusion medicine, Prewarmed tests : Pro-why, when, and how-not if. Transfusion, 35 (3) : 268-269, 1995.

4) Mollison, P.L., et al. : Other red cell antigen. Blood Transfusion in Clinical Medicine, 8th ed, Blackwell Scientific Publications, London, 1987, 373409.

5) Technical manual : 15 Other blood groups. 13th ed, American Association of Blood Banks, 1999, 315 - 338 .

6) Garratty, G. : Abbreviating Pretransfusion (Compatibility) Testing, 「What are the Risk? 」輸血前 （輸血適合）試験の簡略化一どんな危険がある か一. 日本輸血学会雑誌, 37(5)：687-694, 1991.

7) Petz, L.D., et al. : Red cell compatibility testing,
Clinical significance and laboratory methods. Clinical practice of transfusion medicine, 2nd ed, New York, Churchill Livingstone, 1989, 173-211.

8) Issitt, P.D., et al. : Lack of clinical significance of "enzyme-only" red cell alloantibodies. Transfusion, 33 (4) : 284-293, 1993.

9）濱田貴子, 他：冷式抗体保有患者への輸血用血液 の選択時に冷式抗体を無視することの当否. 日本 輸血学会雑誌, 44 (1) : 27-32, 1998.

10) Judd, W.J. : Differentiation of IgM from IgG antibodies-Dithiothreitol. Methods in Immunohematology, 2nd ed, Montgomery scientific publications, 1994,416 -417.

11）松田仁志，他：赤血球抗体保有者への抗原陽性血 の輸血症例一全国国立大学輸血部会議技術懇談 会調查報告一. 日本輸血学会雑誌, 39(2)：457, 1993.

12）児玉（秋林）建：全国大学病院における時間外輸 血業務の実態. 日本輸血学会雑誌, 42(6)：272278, 1996. 